\title{
BIBLIOGRAPHY
}

\section{Archives and libraries consulted}

\section{Bodleian Library, Oxford}

Grigg Papers

\section{British Medical Association Archives, London}

Colindale Newspaper Library, London

Eugenics Society Archive, held at the Contemporary Medical Archives

Centre, Wellcome Institute for the History of Medicine (please note: all material from the Eugenics Society Archive (c) The Galton Institute, London)

House of Lords Records Office, London

Kenya National Archives, Nairobi

The National Archives, Kew, London (formerly the Public Record Office)

Rhodes House Library, Oxford

School of Hygiene and Tropical Medicine Library, London

Kenya and East African Medical Journal/East African Medical Journal

School of Oriental and African Studies Library, London

\section{Official publications}

Royal Commission on the Care and Control of the Feeble-Minded, Minutes of Evidence and Reports, Cmd 4215-4221 (London: HMSO, 1908).

Advisory Committee on Native Education in the British Tropical African

Dependencies, Education Policy in British Tropical African Dependencies,

Cmd 2374 (London: HMSO, 1925).

Report of the Mental Deficiency Committee being a Joint Committee of the Board

of Education and the Board of Control (Wood Report) (London: HMSO, 1929).

Report of the Commission on Closer Union in Eastern and Central Africa (Hilton

Young Report), Cmd 3234 (London: HMSO, 1929).

Memorandum on Native Policy, Cmd 3573 (London: HMSO, 1930).

Report of the Joint Select Committee on Closer Union in East Africa, H. C. 156

(London: HMSO, 1931).

Crime Committee Report (Nairobi: Government Printers, May 1932).

Report of the Commission of Inquiry into the Administration of Justice in Kenya,

Uganda and the Territory of Tanganyika (Bushe Report), Cmd 4623 (London:

HMSO, 1934).

Report of the Committee on Juvenile Crime and Kabete Reformatory (Nairobi,

Government Printers, 1934).

Board of Control, Committee of Sterilisation, Report (Brock Report), Cmd 4485

(London: HMSO, 1934). 
L. S. Penrose, A Clinical and Genetic Study of 1280 Cases of Mental Defect (Colchester Survey), No. 229 in Special Report series (London: HMSO, 1938).

H. Slade et al., Report of the Committee on Young Persons and Children (Nairobi: Government Printers, 1953).

\section{Primary published literature}

Aikman, K. B., 'Race Mixture', Eugenics Review, 25/3 (1933): 161-66.

Arnell, O. R., 'Correspondence', East African Medical Journal, 9/6 (1932): 179-80.

Bateson, W., 'Commonsense in Racial Problems', Eugenics Review, 13/1 (1921): 325-38.

Berry, R. J. A, 'Practical Method for the Detection, during Childhood, of Potential Social Inefficiency and High-Grade Mental Deficiency' in Stoke Park Monographs on Mental Deficiency and Other Problems of the Human Brain and Mind, edited by Berry, R. J. A., pp. 3-39, London: Macmillan, 1933.

Berry, R. J. A, 'Mental Deficiency in England: An Analysis of the Mental, Physical and Mental Characteristics of a Group of 162 Adult Feeble-Minded Women' in Stoke Park Monographs on Mental Deficiency and Other Problems of the Human Brain and Mind, edited by Berry, R. J. A., pp. 65-80, London: Macmillan, 1933.

Berry, R. J. A., 'Unselected Examples of the Hereditary Transmission of Endogenous Amentia' in Stoke Park Monographs on Mental Deficiency and Other Problems of the Human Brain and Mind, edited by Berry, R. J. A., pp. 213-19, London: Macmillan, 1933.

Berry, R. J. A (ed.), Stoke Park Monographs on Mental Deficiency and Other Problems of the Human Brain and Mind, London: Macmillan, 1933.

Burt, Cyril, The Young Delinquent, London: University of London Press, 1925.

Campbell, C., 'Juvenile Delinquency in Colonial Kenya, 1900-1939', The Historical Journal, 45/I (2002): 129-51.

Carman, J. A. and Roberts, M. A. W., 'Social and Health Conditions among the Jaluo, with Special Reference to Maternal and Infant Welfare', East African Medical Journal, 11/4 (1934): 107-24.

Carothers, J. C., 'A Comparison of Two Methods of Skin Grafting', East African Medical Journal, 13/11 (1937): 345.

Carothers, J. C., 'The Female Kikuyu Pelvis in Relation to Labour', East African Medical Journal, 14/8 (1937): 260-1.

Carothers, J. C., 'Some Speculations on Insanity in Africans, and in General', East African Medical Journal, 17/3 (1940): 90-105.

Carothers, J. C., 'Miraa as a Cause of Insanity', East African Medical Journal, 22/1 (1945): 4-6.

Carothers, J. C., 'A Study of Mental Derangement in Africans, and an Attempt to Explain Its Peculiarities, More Especially in Relation to the African Attitude to Life', Journal of Mental Science, 93 (1947): 548-97.

Carothers, J. C., 'The Mental Treatment Ordinance, 1949', East African Medical Journal, 26/5 (1949): 128-36. 
Carothers, J. C., 'Frontal Lobe Function and the African', The Journal of Mental Science, 97 (1951): 12-48.

Carothers, J. C., The African Mind in Health and Disease: A Study in Ethnopsychiatry, Geneva: World Health Organization, 1953.

Carothers, J. C., The Psychology of Mau Mau, Nairobi: Government Printers, 1954.

Carothers, J. C., The Mind of Man in Africa, London: Tom Stacey, 1972.

Cook, A., 'Note on Dr. Mitchell's Paper on the Causes of Obstructed Labour in Uganda', East African Medical Journal, 15/7 (1938): 213-17.

Cook, W. G. H., 'English and Foreign Marriage Law in Relation to Mental Disorder', Eugenics Review, 13/1 (1921): 351-9.

Crewdson Benington, R., 'A Study of the Negro Skull with Special Reference to the Congo and Gaboon Crania', Biometrika, 8/3 and 4 (1912): 292-337.

Crookshank, F. G., The Mongol in Our Midst: A Study of Man and His Three Races, London: Kegan Paul, 1931.

Dahlberg, G., Race, Reason and Rubbish, translated by L. Hogben, London: George Allen and Unwin, 1942.

Dougall, J. W. C., 'Characteristics of African Thought', Africa, 5/3 (1932): 249-65.

Dougall, J. W. C., 'The Development of the Education of the African in Relation to Western Contact', Africa, 11/3 (1938): 312-23.

Dover, C., 'Population Control in India', Eugenics Review, 26/4 (1934): 283-5.

Duerden, J. E., 'Genesis and Reclamation of the Poor White in South Africa', Eugenics Review, 14/4 (1923): 270-5.

EAMJ, 'Kenya Society for the Study of Race Improvement', East African Medical Journal, 10/4 (1933): 155-6.

EAMJ, 'Kenya Society for the Study of Race Improvement', East African Medical Journal, 10/12 (1934): 379.

EAMJ, 'The Kampala Meeting: Resolution on Research in Africa', East African Medical Journal, 13/4 (1936): 122.

EAMJ, 'Mental Degeneracy', East African Medical Journal, 16/4 (1939): 190-1.

EAMJ, 'East African Medical Service Lists', East African Medical Journal, 16/8 (1939): 312-19.

Editorial, British Medical Journal, 30 April (1932): 812-13.

Editorial, 'The Mind and Brain of the Kenya Native', British Medical Journal, 18 November (1933): 931-2.

Editorial, 'The Medical Aspect of Closer Settlement of Europeans in the Kenya Highlands' Kenya and East African Medical Journal, 6/7 (1929): 188-9.

Editorial, East African Medical Journal, 9/2 (1932): 29.

Editorial, East African Medical Journal, 9/10 (1933): 275.

Editorial, East African Medical Journal, 10/12 (1934): 349.

Editorial, 'The Brain of the East African', East African Medical Journal 11/2 (1934): 39-42.

Editorial, East African Medical Journal, 11/7 (1934): 209-10.

Editorial, 'The Medical Education of Africans', East African Medical Journal, 16/5 (1939): 167.

Editorial, East African Medical Journal, 19/1 (1942): 1-2. 
Editorial, 'African Civilizations', East African Medical Journal, 21/8 (1944): 225. Editorial, 'The Training of Native Laboratory Assistants in East Africa', East African Medical Journal, 21/3 (1944): 65-6.

Editorial, East African Medical Journal, 23/12 (1946): 359-60.

Editorial, 'The Brain of the African Native', Lancet, 226/5764 (1934): 357.

Fawcett, C. D., assisted by A. Lee and Others, 'A Second Study of the Variation and Correlation of the Human Skull, with Special Reference to the Naqada Crania', Biometrika, 1/4 (1902): 408-67.

Fick, M. L., The Educability of the South African Native, Issued by the South African Council for Educational and Social Research, Pretoria: The National Bureau, 1939.

Fleming, R. M., 'Human Hybrids', Eugenics Review, 21/4 (1930): 257-63.

Fleure, H. J., 'Some Aspects of Race Study', Eugenics Review, 14/2 (1922): 93-102.

Fleure, H. J., 'The Nordic Myth', Eugenics Review, 22/2 (1930): 117-21.

Fleure, H. J., 'Race and Politics', Eugenics Review, 27/4 (1936): 319-20.

Foiley, E. J., 'Psychiatric Opinion and Crime with Special Reference to Temporary Insanity', East African Medical Journal, 23/5 (1946): 150-4.

Galton, F., Hereditary Genius, London: Macmillan, 1869.

Galton, F., Essays in Eugenics, London: Eugenics Education Society, 1909.

Gates, R. R., 'Heredity and Eugenics. Part II', Eugenics Review, 12/1 (1920): $1-13$.

Gates, R. R., 'Eugenics and Education', Eugenics Review, 23/4 (1932): 305-9.

Gibbons, R. M. and M. J., 'Some Considerations for the Training of African Medical Students', East African Medical Journal, 10/11 (1934): 355-7.

Gilks, J. L., 'The Medical Department and the Health Organization in Kenya, 1909-1923', East African Medical Journal, 9/12 (1933): 340-54.

Gilks, J. L., 'Dietetic Problems in East Africa', East African Medical Journal, 10/9 (1933): 254-65.

Gilks, J. L., 'The Relation of Economic Development to Public Health in Rural Africa', Journal of the African Society, 34/134 (1935): 31-40.

Gilks, J. L. and J. B. Orr, 'The Nutritional Condition of the East African Native', Kenya and East African Medical Journal, 4/3 (1927): 85-90.

Gordon, H. L., Sir James Simpson and Chloroform, London: T. Fisher \& Unwin, 1897.

Gordon, H. L., The Modern Mother: A Guide to Girlhood, Motherhood and Infancy, London: T. Werner Laurie, 1909?

Gordon, H. L., The Prevention of Malaria in the Northern Transvaal, Johannesburg: Argus, 1910.

Gordon, H. L., 'Mental Instability among Europeans in Kenya', Kenya and East African Medical Journal, 4/10 (1928): 316-24.

Gordon, H. L., 'Paranoia; and the Case of Hackman', Kenya and East African Medical Journal, 5/11 (1929): 874-6.

Gordon, H. L., '(1) A Case of Spatial Syndrome (2) Sexual Perversions', Kenya and East African Medical Journal, 6/5 (1929): 122-30. 
Gordon, H. L., 'Relation of Malaria to the Alleged Rarity of Neurosyphilis amongst "Uncivilised" Races', Kenya and East African Medical Journal, 6/8 (1929): 221-9.

Gordon, H. L., 'Some Implications of the Closer Union Report', East African Standard, 13 April (1929): 15-16.

Gordon, H. L., 'Notes on Some Current Literature and Topics', Kenya and East African Medical Journal, 7/4 (1930): 108-16.

Gordon, H. L., 'A Note on the Diagnosis of Amentia (Mental Deficiency) in Africans', Kenya and East African Medical Journal, 7/8 (1930): 208-14.

Gordon, H. L., 'The Social Aspect of the Curious History of Syphilis', Kenya and East African Medical Journal, 7/11 (1931): 320-2.

Gordon, H. L., 'Correspondence. The Educable Capacity of the African', East African Medical Journal, 9/7 (1932): 210-12.

Gordon, H. L., 'Xeropthalmia in Mathari Mental Hospital', East African Medical Journal, 10/3 (1933): 85-90.

Gordon, H. L., 'The Case of Charles William Ross, Hanged for Murder in Kenya Colony' in Stoke Park Monographs on Mental Deficiency and Other Problems of the Human Brain and Mind, edited by Berry, R. J. A., pp. 233-7, London: Macmillan, 1933.

Gordon, H. L., 'Amentia in the East African', Eugenics Review, 25/4 (1934): 223-35.

Gordon, H. L., 'The Basal Metabolism of the East African (Letter to the Editor)', East African Medical Journal, 11/4 (1934): 134.

Gordon, H. L., 'The Intentional Improvement of Backward Tribes', East African Medical Journal, 11/5 (1934): 143-56.

Gordon, H. L., 'The Kenya Native', Eugenics Review, 26/1 (1934): 85-7.

Gordon, H. L., 'Brain and Mind', Eugenics Review, 26/4 (1934): 311.

Gordon, H. L., 'Neurospirochætosis in the East African', Proceedings of the Royal Society of Medicine, 27/Part 1 (1934): 243-54.

Gordon, H. L., 'The Mental Capacity of the African', Journal of the African Society, 33/132 (1934): 226-42.

Gordon, H. L., 'Psychiatry in Kenya Colony', Journal of Mental Science (January, 1934): 167-70.

Gordon, H. L., 'Yaws and Syphilis, Correspondence', East African Medical Journal, 12/7 (1935): 221-2.

Gordon, H. L., 'An Inquiry into the Correlation of Civilization and Mental Disorder in the Kenya Native', East African Medical Journal, 12/11 (1936): 327-35.

Gordon, H. L., 'On Certification of Mental Disorder in Kenya', East African Medical Journal, 12/12 (1936): 358-65.

Gordon, H. L., 'Headache in Kenya', East African Medical Journal, 14/6 (1937): 189-98.

Gordon, H. L., 'The Female Baganda Pelvis', East African Medical Journal, 15/8 (1938): 268-69.

Gordon, H. L., 'The Doctor in the Witness-Box', East African Medical Journal, 18/8 (1941): 236-39. 
Gordon, H. L., 'Is War Eugenic or Dysgenic? That is Does War Improve or Impair the Physical or Mental Qualities of Future Generations', East African Medical Journal, 19/2 (1942): 86-96.

Gordon, H. L., 'The Importance of Social Medicine to Kenya', East African Medical Journal, 23/1 (1946): 2-12.

Graham-Little, E., 'British Empire and Backward Races', Empire Review and Magazine, 66/442 (1937): 269-75.

Gregory, J. R., 'Ante-Natal Care and Carelessness', East African Medical Journal, 16/3 (1939): 104-25.

Grigg, E., The Constitutional Problem in Kenya, Nottingham: University College, Nottingham, 1933.

Hailey, M., An African Survey, London: Oxford University Press, 1938.

Haldane, J. B. S., The Causes of Evolution, London: Longman, Green and Co., 1932.

Haldane, J. B. S., The Inequality of Man and Other Essays, London: Chatto and Windus, 1932.

Haldane, J. B. S., Fact and Faith, London: Watts and Co., 1934.

Haldane, J. B. S., Human Biology and Politics, London: The British Science Guild, 1934.

Haldane, J. B. S., Heredity and Politics, London: George Allen and Unwin, 1938.

Hankins, F. H., 'Civilization and Fertility. Has the Reproductive Power of Western Peoples Declined?', Eugenics Review, 23/2 (1931): 145-50.

Harvey, D. and Vint, F. W., 'A Note on the Post-Mortem Calcium Content of the Blood Serum and Cerebro-Spinal Fluid of the East African Native', Kenya and East African Medical Journal, 8/9 (1931): 240-5.

Healy, W., The Individual Delinquent, New York: Alfred A. Knopf, 1914.

Hentachri, C. C., 'South African Journal of Science', Eugenics Review, 21/1 (1929): 78.

Hentschel, C. C., 'South African Journal of Science', Eugenics Review, 23/1 (1931): 91-92.

Hinde, H., "The "Black Peril" in British East Africa: A Frank Talk to Women Settlers', The Empire Review and Journal of British Trade, 35/245 (1921): 193-200.

Hogben, L., Genetic Principles in Medicine and Social Science, London: Williams and Norgate, 1931.

Hogben, L., Nature and Nurture, London: Williams and Northgate, 1933.

Hogben, L., The Retreat from Reason, London: Watts and Co., 1936.

Holmes, S. J., 'Natural Selection in Man', Eugenics Review, 22/1 (1930): 7-16.

Hubback, E. and Green, M. E., 'Family Endowment', Eugenics Review, 25/1 (1933): 33-6.

Huxley, J. and Haddon, A. C., We Europeans: A Survey of 'Racial Problems', London: Jonathan Cape, 1935.

Huxley, J., Africa View, London: Chatto \& Windus, 1931.

Huxley, J., 'Eugenics and Society', Eugenics Review, 28/1 (1936): 11-31.

Huxley, J., Memories, Vol. I, London: Allen and Unwin, 1970. 
Hyam, R., Empire and Sexuality: The British Experience, Manchester: Manchester University Press, 1992.

Josey, C. C., Race and National Solidarity, New York: Charles Scribner and Sons, 1923.

Kenyatta, J., Facing Mount Kenya, London: Secker and Warburg, 1938.

Langdon Brown, W., 'The Mongol in Our Midst', Eugenics Review, 23/1 (1931): 251-3.

Latham, D. V., 'The White Man in East Africa', East African Medical Journal, 9/10 (1933): 276-82.

Leakey, L. S. B., Mau Mau and the Kikuyu, London: Methuen, 1952.

Leakey, L. S. B., Defeating Mau Mau, London: Methuen, 1955.

Leys, N., Kenya, London: The Hogarth Press, 1924.

Lidbetter, E. J., 'The Social Problem Group as Illustrated by a Series of East London Pedigrees', Eugenics Review, 24/1 (1932): 7-12.

Loewenthal, L. J. A., 'The Significance of Colour Changes in African Skin', East African Medical Journal, 11/4 (1934): 124-31.

Loewenthal, L. J. A., 'The Effect of the Addition of Milk to the Diet of Schoolboys in Buganda', East African Medical Journal, 15/1 (1938): 35-45.

Ludovici, A. M., 'Feminism and Science', Eugenics Review, 21/1 (1929): 50-1.

Lundborg, H., 'The Danger of Degeneracy', Eugenics Review, 13/4 (1921): 531-9.

MacCrone, I. D., Race Attitudes in South Africa, London: Oxford University Press, 1937.

Mackay, D., 'A Background for African Psychiatry', East African Medical Journal, 25/1 (1948): 2-4.

Mackinnon, M., 'Medical Aspects of White Settlement in Kenya', East African Medical Journal, 11/12 (1935): 376-93.

Mayhew, A., 'A Comparative Survey of Educational Aims and Methods in British India and British Tropical Africa', Africa, 6/2 (1933): 172-86.

McCardie, Justice, 'My Outlook on Eugenics', Eugenics Review, 25/1 (1933): 7-14.

McDougall, W., National Welfare and National Decay, London: Methuen, 1921.

Michener, R. B., 'Correspondence. The Birth Weight of Africans', East African Medical Journal, 9/5 (1932): 149.

Michener, R. B., 'Queries on Native Circumcision', East African Medical Journal, 13/11 (1937): 378-81.

Mitchell, J. P., 'On the Causes of Obstructed Labour in Uganda', East African Medical Journal, 15/6 (1938): 177-89.

Mitchell, J. P., 'On the Causes of Obstructed Labour in Uganda. Part II', East African Medical Journal, 15/7 (1938): 206-12.

Mjoen, J. A., 'Race-Crossing and Glands. Some Human Hybrids and their Parental Stock', Eugenics Review, 23/1 (1931): 31-40.

Mockerie, P., An African Speaks for His People, London: The Hogarth Press, 1934.

Moore, E., 'Amentia in South Africa', Eugenics Review, 23/3 (1931): 239.

Muwazi, E. and Trowell, H., 'Neurological Disease among African Natives of Uganda: A Review of 269 Cases', East African Medical Journal, 21/1 (1944): 2-19. 
Nature, 'European Civilisation and African Brains', Nature, 132/3347 (1933): 958.

Nielsen, P., The Black Man's Place in South Africa, Cape Town: Juta and Co., 1922.

Notes and Memoranda, 'The African Brain', Eugenics Review, 26/1 (1934): 51.

O'Brien, T. P., 'The Methods and Aims of the Race Relations Institute', East African Medical Journal, 23/12 (1946): 361-84.

Oldham, J. H., 'The Educational Work of Missionary Societies', Africa, 7/1 (1934): 47-59.

Oliver, R. A. C., 'The Comparison of the Abilities of Races: With Special Reference to East Africa', East African Medical Journal, 9/6 (1932): 160-75.

Oliver, R. A. C., 'The Comparison of the Abilities of Races: With Special Reference to East Africa [Concluded]', East African Medical Journal, 9/7 (1932): 193-204.

Oliver, R. A. C., 'Mental Tests in the Study of the African', Africa, 7/1 (1934): $40-46$.

Oliver, R. A. C., The Training of Teachers in Universities, Bickley (wartime address): University of London Press, 1943.

Oliver, R. A. C., Research in Education, London: Allen and Unwin, 1946.

Onslow, H., 'Fair and Dark; Is There a Predominant Type?', Eugenics Review, 12/3 (1920): 212-17.

Orr, J. B., Food, Health and Income. Report on the Inadequacy of Diet in Relation to Income, London: Macmillan, 1936.

Paterson, A., 'Nutrition and Agriculture', East African Medical Journal, 17/2 (1940): 51-9.

Paterson, A. R., 'The Education of Backward Peoples', East African Medical Journal, 8/11 (1932): 302-15.

Paterson, A. R., On Various Public Health Questions, Health Pamphlet No. 13: Colony and Protectorate of Kenya, Medical Department, 1937.

Pearl, R., 'Variation and Correlation in Brain Weight', Biometrika, 4/1 and 2 (1905): 13-104.

Pearson, K., National Life from the Standpoint of Science, London: Black and Co., 1901.

Pearson, K., Social Problems: Their Treatment, Past, Present and Future, London: Cambridge University Press, 1912.

Pearson, K., Eugenics and Public Health. An Address to Public Health Officers, London: Dulau and Co., 1912.

Pearson, K., The Function of Science in the Modern State, Cambridge: Cambridge University Press, 1919.

Penrose, L. S., Mental Defect, London: Sidgwick and Jackson, 1933.

Penrose, L. S., 'The Complex Determinants of Amentia', Eugenics Review, 26/2 (1934): 121-6.

Perham, M. (ed.), Ten Africans, London: Faber and Faber, 1936.

Philip, C. R., 'Nutrition in Kenya: Notes on the State of Nutrition of African Children', East African Medical Journal, 20/7 (1943): 227-34. 
Pitt-Rivers, G. H. L.-F., 'Sex-Ratios and Marriage', Eugenics Review, 21/1 (1929): 21-8.

Pocock, H. A., 'Sterilization in the Empire. An Account of the Working of the Alberta Act', Eugenics Review, 24/2 (1932): 127-30.

Preston, P. G., 'Notes on Two Years' Maternity Work amongst the South Kavirondo (Kenya) Natives (215 cases)', East African Medical Journal, 13/7 (1936): 215-23.

Quick, Griffith, 'General Intelligence Test for Africans: Manual for Direction', Africa, 7/2 (1934): 149.

Raymond, W., 'Minimum Dietary Standards for East African Natives', East African Medical Journal, 17/7 (1940): 249-65.

Ritchie, J. F., The African as Suckling and as Adult (A Psychological Study), The Rhodes-Livingstone Papers, Number 9, The Rhodes-Livingstone Institute, 1943.

Roberts, J. and Dick, D. A., 'Notes on the Control of Bed-Bugs (Cimex Rotundatus)', East African Medical Journal, 12/1 (1935): 46-57.

Saleeby, C. W., Parenthood and Race Culture, London: Cassell, 1909.

Schiller, F. C. S., 'Eugenics versus Civilization', Eugenics Review, 13/2 (1921): 381-93.

Schofield, A. T., 'Scientific Diets for African Children', East African Medical Journal, 13/8 (1936): 230-45.

Schuster, E. and Elderton, E., The Inheritance of Ability, being a Statistical Study of the Oxford Class Lists and of the School Lists of Harrow and Charterhouse, London: Dulau and Co., 1907.

Scott, H. S., 'A Note on the Educable Capacity of the African', East African Medical Journal, 9/4 (1932): 99-110.

Sequeira, J. H., 'The Brain of the East African Native', British Medical Journal, 1 (1932): 581.

Sequeira, J. H., 'The Influence of Light and Heat on the Human Body', East African Medical Journal, 8/12 (1932): 332-58.

Sequeira, J. H., 'Correspondence. The Educable Capacity of the African, East African Medical Journal, 9/5 (1932): 146-8.

Sequeira, J. H., 'Heredity and Disease: The Story of the Abbé Gillet's Rabbits', East African Medical Journal, 10/11 (1934): 331-5.

Shaw Bolton, J., The Brain in Health and Disease, London: Edward Arnold, 1914.

Shaw Bolton, J., The Cortical Localisation of the Cerebral Function, Edinburgh: Oliver and Boyd, 1933.

Shaw, M. Michael, 'Child Welfare', East African Medical Journal, 8/10 (1932): 284-94.

Shaw, M. Michael, 'The Birth-Weight of Africans', East African Medical Journal, 10/1 (1933): 32-4.

Shaw, Mary M., 'Correspondence. The Birth Weight of Africans', East African Medical Journal, 9/6 (1932): 180.

Sherrington, C., The Brain and Its Mechanism, Cambridge: Cambridge University Press, 1933. 
Smartt, C. G. F., 'Mental Maladjustment in the East African', Journal of Mental Science, 102 (1956): 441-66.

Speller, C., Great Britain's Reward to the Kenya Native Ex-Service Man, Aberystwyth, 1931.

Stock, C. S., 'The Sex Ratio and Emigration', Eugenics Review, 10/3 (1918): 163-6.

Stones, R. Y., 'Twenty-Five Years of Tropical Medicine', East African Medical Journal, 13/9 (1936): 271-81.

Stones, R. Y., 'On the Causes of Obstructed Labour in Uganda', East African Medical Journal, 15/7 (1938): 217-19.

Terman, Lewis, The Intelligence of School Children: How Children Differ in Ability, the Use of Mental Tests in School Grading and the Proper Education of Exceptional Children, London: Harrap and Co., 1921.

Thomson, G. H., A Modern Philosophy of Education, London: George Allen and Unwin, 1929.

Thomson, G. H., Instinct, Intelligence, and Character: An Educational Psychology, London: Allen and Unwin, 1932.

Thomson, G. H., The Factoral Analysis of Human Ability, London: University of London Press, 1939.

Thomson, G. H., The Trend of National Intelligence: The Galton Lecture, 1946, London: The Eugenics Society and Hamish Hamilton Medical Books, 1947.

Thomson, G. H., The Education of an Englishman: An Autobiography, Edinburgh: Moray House Publications, 1969.

Tonking, H. D., 'The Red Cell Count and Cell Diameter of Kenya Natives', East African Medical Journal, 13/2 (1936): 43-9.

Tredgold, A. F., 'Inheritance and Educability', Eugenics Review, 13/1 (1921): 339-50.

Tredgold, A. F., Mental Deficiency (Amentia), fifth edition (largely re-written), London: Bailliere, Tindall and Cox, 1929.

Tredgold, A. F., A Text-Book of Mental Deficiency (Amentia), sixth edition, London: Bailliere, Tindall and Cox, 1937.

Trowell, H. C., 'The Medical Training of Africans', East African Medical Journal, 11/11 (1935): 338-53.

Vint, F. W., 'Gall Stones in a Native Child', Kenya and East African Medical Journal, 5/2 (1928): 59-61.

Vint, F. W., 'One Year's Post-Mortem Work on Natives of East Africa', Kenya and East African Medical Journal, 5/12 (1929): 383-93.

Vint, F. W., 'Cirrhosis of the Liver of the East African Native', Kenya and East African Medical Journal, 7/12 (1931): 349-75.

Vint, F. W., 'Notes on the Pathology of Syphilis', Kenya and East African Medical Journal, 8/4 (1931): 94-101.

Vint, F. W., 'A Preliminary Note on the Cell Content of the Prefrontal Cortex of the East African Native', East African Medical Journal, 9/2 (1932): 30-55.

Vint, F. W., 'The Brain of the Kenya Native', Journal of Anatomy, 68/2 (1934): $216-23$. 
Vint, F. W., 'Post-Mortem Findings in the Natives of Kenya', East African Medical Journal, 13/11 (1937): 332-44.

Vint, F. W., 'The Measurement of Red Blood Corpuscles', East African Medical Journal, 16/8 (1939): 295-307.

Vint, F. W., 'Some Recent Researches on the Spleen and Their Possible Relationship to Blackwater Fever', East African Medical Journal, 18/6 (1941): 162-73.

Vint, F. W., 'The Pathology of Plague', East African Medical Journal, 19/1 (1942): 9-14.

Vint, F. W., 'Solar Rays. Fact or Fiction?', East African Medical Journal, 21/8 (1944): 227-39.

von Economo, Constanin, The Cyroarchitectonics of the Human Cerebral Cortex, London: Oxford University Press, 1929.

Walter, A., 'Brain and Mind', Eugenics Review, 26/4 (1934): 311-12.

Walter, A., 'Climate and White Settlement in the East African Highlands', East African Medical Journal, 11/7 (1934): 210-25.

Watson, W., 'A Case of Sexual Perversion in an African Male', East African Medical Journal, 20/10 (1943): 354.

Westermann, D., The African To-Day, London: Oxford University Press, 1934.

Whetham, W. C. D. and C. D., 'The Influence of Race in History' in Problems in Eugenics - Papers Communicated to the First International Eugenics Congress, pp. 237-46, London: Eugenics Education Society, 1912.

\section{Secondary literature}

Adams, M. B., 'Towards a Comparative History of Eugenics' in The Wellborn Science. Eugenics in Germany, France, Brazil, and Russia, edited by Adams, M. B., pp. 217-31. Oxford: Oxford University Press, 1990.

Adams, M. B. (ed.), The Wellborn Science. Eugenics in Germany, France, Brazil, and Russia, Oxford: Oxford University Press, 1990.

Adebola, A. S., 'The London Connection: A Factor in the Survival of the Kikuyu Independent Schools Movement, 1929-39', Journal of African Studies, 10/1 (1983): 14-23.

Anderson, D. M., 'Depression, Dustbowl, Demography, and Drought: The Colonial State and Soil Conservation in East Africa during the 1930s', African Affairs, 83/332 (1984): 321-43.

Anderson, D. M., 'Policing, Prosecution and the Law in Colonial Kenya, c. 1905-1939', in Policing the Empire. Government, Authority and Control, 1830-1940, edited by Anderson, D. M. and Killingray, D., pp. 183-200, Manchester: Manchester University Press, 1991.

Anderson, D. M., 'Black Mischief: Crime, Protest and Resistance in Colonial Kenya', Historical Journal, 36/4 (1993): 851-77.

Anderson, D. M., 'The "Crisis of Capitalism" and Kenya's Social History: A Comment", African Affairs, 92 (1993): 285-90.

Anderson, D. M., Histories of the Hanged: Britain's Dirty War and the End of Empire, London: Weidenfeld and Nicolson, 2005. 
Anderson, D. M. and D. Killingray, 'Consent, Coercion and Colonial Control: Policing the Empire, 1830-1940' in Policing the Empire. Government, Authority and Control, 1830-1940, edited by Anderson, D. M. and Killingray, D., pp. 1-15, Manchester: Manchester University Press, 1991.

Arnold, D. (ed.), Imperial Medicine and Indigenous Societies, Manchester: Manchester University Press, 1988.

Arrighi, G., 'The Political Economy of Rhodesia' in Essays on the Political Economy of Africa, edited by Arrighi, G. and Saul, J. S., pp. 336-77, New York: Monthly Review Press, 1973.

Askwith, T., The Story of Kenya's Progress, Nairobi: The Eagle Press, 1953.

Askwith, T., From Mau Mau to Harambee: Memoirs and Memoranda of Colonial Kenya, Cambridge: African Studies Centre, 1995.

Banton, M., The Idea of Race, London: Tavistock Publications, 1977.

Banton, M., Racial Theories, Cambridge: Cambridge University Press, 1987.

Banton, M., 'Galton's Conception of Race in Historical Perspective' in Sir Francis Galton, FRS. The Legacy of His Ideas. Proceedings of the Twenty-Eighth Annual Symposium of the Galton Institute, London, edited by Keynes, M., pp. 170-9, London: Macmillan, 1993.

Barkan, E., The Retreat of Scientific Racism: Changing Concepts of Race in Britain and the United States between the World Wars, Cambridge: Cambridge University Press, 1992.

Barker, D., 'How to Curb the Unfit: The Feeble-Minded in Edwardian Britain', Oxford Review of Education, 9/3 (1983): 197-211.

Beck, A., A History of the British Medical Administration of East Africa, 1900-1950, Cambridge, Massachusetts: Harvard University Press, 1970.

Beinart, W. and Dubow, S. (eds), Segregation and Apartheid in Twentieth-Century South Africa, London: Routledge, 1995.

Bennett, G., 'Imperial Paternalism: The Representation of African Interests in the Kenya Legislative Council' in Essays in Imperial Government Presented to Margery Perham, edited by Robinson, K. and Madden, F., pp. 141-69, Oxford: Basil Blackwell, 1963.

Bennett, G., Kenya, A Political History: The Colonial Period, London: Oxford University Press, 1963.

Bennett, G., 'Settlers and Politics in Kenya up to 1945' in Oxford History of East Africa, Harlow, V. and Chilver, E. M. (eds), pp. 265-332, Oxford: Oxford University Press, 1965.

Bennett, J. H. (ed.), Natural Selection, Heredity, and Eugenics. Including Selected Correspondence of R. A. Fisher with Leonard Darwin and Others, Oxford: Clarendon Press, 1983.

Berman, B., Control and Crisis in Colonial Kenya, The Dialectic of Domination, London: James Currey, 1990.

Berman, B. and Lonsdale, J., Unhappy Valley, Vol. 1: State and Class, 2: Violence and Ethnicity, Oxford: James Curry, 1992.

Berry, V. (ed.), The Culwick Papers, 1934-1944: Population, Food and Health in Colonial Tanganyika, London: Academy Books, 1994. 
Berry, V. and Petty, C. (eds), The Nyasaland Survey Papers, 1938-1943: Agriculture, Food and Health, London: Academy Books, 1992.

Billig, M., 'The Origins of Race Psychology', Patterns of Prejudice, 16/3 (1982): 4.

Blacker, C. P., 'The Press and Eugenics: A Review of Reviews', Eugenics Review, 26/3 (1934): 207-12.

Blacker, C. P., Eugenics. Galton and After, London: Duckworth and Co., 1952.

Blacker, C. P., 'Galton's View on Race' in Eugenics. Galton and After, pp. 323-8. London: Duckworth, 1952.

Blanch, M., 'Imperialism, Nationalism and Organized Youth' in Working Class Culture: Studies in History and Theory, edited by Clark, J., Critcher, C. and Johnson, R., pp. 103-20, London: Hutchinson, 1979.

Blixen, Karen, Out of Africa, London: Penguin, 1954.

Bowler, P. J., The Non-Darwinian Revolution: Reinterpreting a Historical Myth, Baltimore and London: The Johns Hopkins University Press, 1992.

Breman, J. (ed.), Imperial Monkey Business. Racial Supremacy in Social Darwinist Theory and Colonial Practice, Amsterdam: VU University Press, 1990.

Brett, E. A., Colonialism and Underdevelopment in East Africa: The Politics of Economic Change, 1919-1939, London: Heinemann, 1979.

Callan, H. and Ardener, S. (eds), The Incorporated Wife, London: Croom Helm, 1984.

Carman, J. A., A Medical History of the Colony and Protectorate of Kenya. A Personal Memoir, London: Rex Collings, 1976.

Carnegie, V. M., Kenyan Farm Diary, Edinburgh: William Blackwood and Sons, 1930.

Childs, Donald J., Modernism and Eugenics: Woolf, Yeats and the Culture of Degeneration, Cambridge: Cambridge University Press, 2001

Clayton, A. and Savage, D., Government and Labour in Kenya, 1895-1963, London: Frank Cass, 1974.

Cleminson, R., 'Eugenics by Name or by Nature? The Spanish Anarchist Sex Reform of the 1930s', History of European Ideas, 18/5 (1994): 729-40.

Conklin, A. L., A Mission to Civilize. The Republican Idea of Empire in France and West Africa, 1895-1930, Stanford, California: Stanford University Press, 1997.

Constantine, Stephen, The Making of British Colonial Development Policy, 1914-1940, London: Frank Cass, 1984.

Darwin, L., 'Eugenics and Imperial Development', Eugenics Review, 11/3 (1919): 124-35.

Dikötter, F., 'Race Culture: Recent Perspectives on the History of Eugenics', American Historical Review, 103/2 (1998): 467-78.

Dilley, M. R., British Policy in Kenya Colony, New York: Thomas Nelson and Sons, 1937.

Dowbiggin, I. R., Keeping America Sane: Psychiatry and Eugenics in the United States and Canada, 1880-1940, Ithaca: Cornell University Press, 1997.

Drouard, A., 'Eugenics in France and Scandinavia: Two Case Studies' in Essays in the History of Eugenics, edited by Peel, R., pp. 173-207, London: The Galton Institute, 1998. 
Dubow, S., 'Race, Civilisation and Culture: The Elaboration of Segregationist Discourse in the Inter-War Years' in The Politics of Race, Class and Nationalism in Twentieth Century South Africa, edited by Marks, S. and Trapido, S., pp. 71-94, London: Longman, 1987.

Dubow, S., Scientific Racism in Modern South Africa, Cambridge: Cambridge University Press, 1995.

Dubow, S. (ed.), Science and Society in Southern Africa, Manchester: Manchester University Press, 2000.

Duder, C. J. D., "'Men of the Officer Class": the Participants in the 1919 Soldier Settlement Scheme in Kenya', African Affairs, 92 (1993): 69-87.

Duder, C. J. D. and Youé, C. P., 'Paice's Place: Race and Politics in Nanyuki District, Kenya, in the 1930s', African Affairs, 93 (1994): 253-78.

East Africa Women's League, They Made It Their Home, Nairobi: East African Standard Ltd, 1962.

Elkins, C., Britain's Gulag: The Brutal End of Empire in Kenya, London, Jonathan Cape, 2005.

Engels, D. and Marks, S. (eds), Contesting Colonial Hegemony: State and Society in Africa and India, London: British Academic Press, 1994.

Ernst, W., 'The European Insane in British India, 1800-1858: A Case Study in Psychiatry and Colonial Rule' in Imperial Medicine and Indigenous Societies, edited by Arnold, D., pp. 27-44, Manchester: Manchester University Press, 1988.

Farrall, L., 'The History of Eugenics: a Bibliographical Review', Annals of Science, 36 (1979): 111-23.

Farrall, L., The Origins and Growth of the English Eugenics Movement, 1865-1925, New York: Garland Publishing, 1985.

Foran, W. R., The Kenya Police 1887-1960, London: Robert Hale, 1962.

Forrest, D. W., Francis Galton. The Life and Work of a Victorian Genius, Elek, 1974.

Freeden, M., 'Eugenics and Progressives: A Study in Ideological Affinity', Historical Journal, 22/3 (1979): 645-71.

Freeden, M., 'Eugenics and Ideology', Historical Journal, 26/4 (1983): 959-62.

Fryer, P., Staying Power, the History of Black People in Britain, London: Pluto, 1984.

Furedi, F., 'The African Crowd in Nairobi: Popular Movements and Elite Politics', Journal of African History, 14/2 (1973): 275-90.

Furley, O. W. and Watson, T., A History of Education in East Africa, New York: NOK Publishers, 1978.

Ghai, Y. P. and McAuslan, J. P. W. B., Public Law and Political Change in Kenya. A Study of the Legal Framework of Government from Colonial Times to the Present, London: Oxford University Press, 1970.

Giliomee, H., 'Processes in the Development of the South African Frontier' in The Frontier in History, edited by Lamar, H. and Thompson, L., pp. 76-119, New Haven: Yale University Press, 1981.

Gillett, M., Tribute to Pioneers. Mary Gillett's Index of Many of the Pioneers of East Africa, Oxford: J. M. Considine (published privately), 1986. 
Gillis, J., 'The Evolution of Juvenile Delinquency in England', Past and Present, 67 (1975): 96-126.

Gilroy, P., 'There Ain't No Black in the Union Jack': The Cultural Politics of 'Race' and Nation, London: Routledge, 1987.

Gould, S. J., The Mismeasure of Man, London: Penguin Books, 1997.

Graham, L. R., 'Science and Values: The Eugenics Movement in Germany and Russia in the 1920s', American Historical Review, 83/5 (1978): 1135-64.

Gregory, J. R., Under the Sun (A Memoir of Dr R. W. Burkitt of Kenya), Nairobi, privately published, 1951.

Gregory, R. G., Sidney Webb and East Africa: Labour's Experiment with the Doctrine of Native Paramountcy, Berkeley: University of California Press, 1962.

Hall, L., 'Women, Feminism and Eugenics' in Essays in the History of Eugenics, edited by Peel, R., pp. 36-51, London: The Galton Institute, 1998.

Halliday, R. J., 'Social Darwinism: A Definition', Victorian Studies, 14/4 (1971): 389-405.

Harlow, V. and Chilver, E. M. (eds), Oxford History of East Africa, Vol. II., Oxford: Oxford University Press, 1965.

Halliday, John, Darwinism, Biology and Race, Working Paper no. 49, University of Warwick, 1990.

Hartz, L., The Founding of New Societies, New York: Harcourt Brace and World, 1964.

Hetherington, P., British Paternalism and Africa, 1920-1940, London: Frank Cass, 1978.

Hetherington. P., 'Explaining the Crisis of Capitalism in Kenya', African Affairs, 92 (1993): 89-103.

Hobsbawm, E., 'The Fabians Reconsidered' in Labouring Men: Studies in the History of Labour, London: Weidenfeld and Nicolson, 1968.

Humphries, Stephen, Hooligans or Rebels?, An Oral History of Working Class Childhood and Youth, 1889-1939, Oxford: Blackwell, 1981.

Huxley, E., White Man's Country: Lord Delamere and the Making of Kenya, Volumes I and II, London: Macmillan, 1935.

Huxley, E., No Easy Way. A History of the Kenya Farmers' Association and Unga Limited, Nairobi: The East African Standard, 1957.

Huxley, E. (ed.), Nellie. Letters from Africa, London: Weidenfeld and Nicolson, 1973.

Huxley, E. and Perham, M., Race and Politics in Kenya, London: Faber and Faber, 1944.

Hyslop, J., 'White Working-Class Women and the Invention of Apartheid: "Purified" Afrikaner Nationalist Agitation for Legislation against "Mixed Marriages", 1934-9', Journal of African History, 36/1 (1995): 57-81.

Iliffe, J., East African Doctors, Cambridge: Cambridge University Press, 1998.

Jeffries, C., The Colonial Office, London: Allen and Unwin, 1956.

Jones, G., Social Darwinism in English Thought: The Interaction between Biological and Social Theories, Brighton: Harvester Press, 1980. 
Jones, G., 'Eugenics and Social Policy between the Wars', Historical Journal, 25/3 (1982): 717-28.

Jones, G., Social Hygiene in Twentieth Century Britain, London: Croom Helm, 1986.

Jones, G., 'The Theoretical Foundations of Eugenics' in Essays in the History of Eugenics, edited by Peel, R., pp. 1-19, London: The Galton Institute, 1998.

Kanogo, T., 'Rift Valley Squatters and Mau Mau', Kenya Historical Review, 5 (1977): 243-53.

Kennedy, D., Islands of White: Settler Society and Culture in Kenya and Southern Rhodesia, 1890-1939, Durham: Duke University Press, 1987.

Kevles, D., 'Genetics in the United States and Great Britain 1890-1930: A Review with Speculations' in Biology, Medicine and Society 1840-1940, edited by Webster, C., pp. 193-215, Cambridge: Cambridge University Press, 1981.

Kevles, D., In the Name of Eugenics: Genetics and the Uses of Human Heredity, Cambridge, Mass.: Harvard University Press, 1995.

Kevles, D., 'Eugenics in North America' in Essays in the History of Eugenics, edited by Peel, R., pp. 208-26. London: The Galton Institute, 1998.

Kiernan, V., The Lords of Human Kind. European Attitudes to Other Cultures in the Imperial Age, London: Serif, 1995.

Killingray, D. and Ellis, S., 'Introduction', African Affairs, 99/395 (2000): 177-82.

King, K. J., 'The Politics of Agricultural Education for Africans in Kenya' in Hadith 3, edited by Ogot, B. A., 142-56. Nairobi: East African Publishing House, 1971.

King, K. J., Pan-Africanism and Education: A Study of Race Philanthropy and Education in the Southern States of America and East Africa, Oxford: Clarendon Press, 1971.

Kipkorir, B. E., 'The Functionary in Kenya's Colonial System' in Biographical Essays on Imperialism and Collaboration in Colonial Kenya, edited by Kipkorir, B. E., pp. 1-14, Nairobi: Kenya Literature Bureau, 1980.

Kitching, G., Class and Economic Change in Kenya, London: Yale University Press, 1980.

Klausen, S., "For the Sake of Race": Eugenic Discourses of Feeblemindedness and Motherhood in the South African Medical Record, 1903-1926', Journal of Southern African Studies, 23/1 (1997): 27-50.

Klausen, S., 'The Race Welfare Society: Eugenics and Birth Control in Johannesburg, 1930-40' in Science and Society in Southern Africa, edited by Dubow, S., pp. 164-87, Manchester: Manchester University Press, 2000.

Klausen, S. M., Race, Maternity and the Politics of Birth Control in South Africa, 1910-39, Basingstoke: Macmillan, 2004.

Kline, P., 'Ninety Years of Psychometrics' in Essays in the History of Eugenics, edited by Peel, R., pp. 128-55, London: The Galton Institute, 1998.

Kohn, M., The Race Gallery, London: Vintage, 1995.

Kopytoff, I. (ed.), The African Frontier: The Reproduction of Traditional African Societies, Bloomington: Indiana University Press, 1987.

Lamar, H. and Thompson, L. (eds), The Frontier in History: North America and Southern Africa Compared, New Haven: Yale University Press, 1981. 
Langford, C., 'The Eugenics Society and the Development of Demography in Britain: The International Population Union, the British Population Society and the Population Investigation Committee' in Essays in the History of Eugenics, edited by Peel, R., pp. 81-111, London: The Galton Institute, 1998.

Lewis, J., Empire State-Building: War and Welfare in Kenya, 1925-52, Oxford: James Currey, 2000.

Leys, C., Underdevelopment in Kenya: The Political Economy of Neo-colonialism, 1964-1971, London: Heinemann, 1975.

Lonsdale, J. M., 'Some Origins of Nationalism in East Africa', Journal of African History, 9/1 (1968): 119-46.

Lonsdale, J. M., 'European Attitudes and African Pressures: Missions and Government in Kenya between the Wars' in Hadith 2, edited by Ogot, B. A., pp. 229-42, Nairobi: East African Publishing House, 1970.

Lonsdale, J. M., 'Mau Maus of the Mind: Making Mau Mau and Remaking Kenya', Journal of African History, 31 (1990): 393-422.

Lonsdale, J. M., 'The Moral Economy of Mau Mau' in Unhappy Valley: Conflict in Kenya and Africa, Book Two: Violence and Ethnicity, edited by Berman, B. and Lonsdale, J. M., pp. 265-504, Oxford: James Currey, 1992.

Love, R., "Alice in Eugenics-Land": Feminism and Eugenics in the Scientific Careers of Alice Lee and Ethel Elderton', Annals of Science, 36 (1936): 145-58.

Low, D. A., 'British East Africa: the Establishment of British Rule' in Oxford History of East Africa, edited by Harlow, V. and Chilver, E. M., Oxford: Oxford University Press, 1965.

Low, D. A. and Smith, A. (eds), Oxford History of East Africa, Vol. III, Oxford: Clarendon Press, 1976.

Lugumba, S. M. E. and Ssekamwa, J. C., A History of Education in East Africa (1900-1973), Kampala: Kampala Bookshop, 1973.

MacKenzie, D., 'Eugenics in Britain', Social Studies of Science, 6 (1976): 499-532.

MacKenzie, D., 'Karl Pearson and the Professional Middle Class', Annals of Science, 36 (1979): 125-43.

MacKenzie, D., 'Sociobiologies in Competition: the Biometrician-Mendelian Debate' in Biology, Medicine and Society 1840-1940, edited by Webster, C., pp. 243-88, Cambridge: Cambridge University Press, 1981.

MacKenzie, D., Statistics in Britain, 1865-1930: The Social Construction of Scientific Knowledge, Edinburgh: Edinburgh University Press, 1981.

Mackenzie, F., Land, Ecology and Resistance in Kenya, 1880-1952, Edinburgh: Edinburgh University Press, 1988.

MacKenzie, J. M., Propaganda and Empire: the Manipulation of British Public Opinion, 1880-1960, Manchester: Manchester University Press, 1986.

MacKenzie, J. M. (ed.), Imperialism and Popular Culture, Manchester: Manchester University Press, 1986.

MacKenzie, J. M., The Empire of Nature: Hunting, Conservation and British Imperialism, Manchester: Manchester University Press, 1988.

Malik, K., The Meaning of Race: Race, History and Culture in Western Society, Basingstoke: Macmillan Press, 1996. 
Malowany, M., 'Unfinished Agendas: Writing the History of Medicine of SubSaharan Africa', African Affairs, 99/395 (2000): 325-49.

Mangan, J. A., The Games Ethic and Imperialism. Aspects of the Diffusion of an Ideal, Harmondsworth: Penguin, 1986.

May, M., 'Innocence and Experience: The Evolution of the Concept of Juvenile Delinquency in the Mid-Nineteenth Century', Victorian Studies, 18/1 (1973): 2-29.

Mazumdar, P., 'The Eugenists and the Residuum: The Problem of the Urban Poor', Bulletin of the History of Medicine, 54/2 (1980): 204-15.

Mazumdar, P., Eugenics, Human Genetics and Human Failings. The Eugenics Society, Its Sources and Its Critics in Britain, London: Routledge, 1992.

McClintock, A., Imperial Leather. Race, Gender and Sexuality in the Colonial Contest, New York: Routledge, 1995.

McCulloch, J., Colonial Psychiatry and 'the African Mind', Cambridge: Cambridge University Press, 1995.

Middleton, John, 'Kenya: Administration and Changes in African Life, 1912-45' in Oxford History of East Africa, edited by Harlow, V. and Chilver, E. M., pp. 333-92, Oxford: Oxford University Press, 1965.

Morris, H. F. and Read, J. S., Indirect Rule and the Search for Justice. Essays in East African Legal History, Oxford: Clarendon Press, 1972.

Mosley, P., The Settler Economies: Studies in the Economic History of Kenya and Southern Rhodesia, 1900-1963, Cambridge: Cambridge University Press, 1983.

Mungeam, G. H., British Rule in Kenya, 1895-1912: The Establishment of Administration in the East Africa Protectorate, Oxford: Clarendon Press, 1966.

Ndungo, J. B., 'Gituamba and Kikuyu Independency in Church and School' in Ngano, Studies in Traditional and Modern East African History, edited by McIntosh, B. G., pp. 131-50, Nairobi: East African Publishing House, 1969.

Norton, B., 'Psychologists and Class' in Biology, Medicine and Society 1840-1940, edited by Webster, C., pp. 289-314, Cambridge: Cambridge University Press, 1981.

Nye, R. A., 'The Rise and Fall of the Eugenics Empire: Recent Perspectives on the Impact of Biomedical Thought in Modern Society', Historical Journal, 36/3 (1993): 687-700.

Odhiambo, E. S. A., The Paradox of Collaboration and Other Essays, Nairobi: Kenya Literature Bureau, 1974.

Ogot, B. A. (ed.), Hadith 2, Nairobi: East African Publishing House, 1970.

Ogot, B. A. (ed.), Hadith 3, Nairobi: East African Publishing House, 1971.

Orr, J. B., As I Recall, London: MacGibbon and Kee Ltd., 1966.

Packard, R. M., White Plague, Black Labour. Tuberculosis and the Political Economy of Health and Disease in South Africa, Pietmaritzburg, 1990.

Paice, E., Lost Lion of Empire: The Life of 'Cape-to-Cairo' Grogan, London: HarperCollins, 2001.

Parkinson, C., The Colonial Office from Within, 1909-1945, London: Faber and Faber, 1947. 
Patton, A., Physicians, Colonial Racism, and Diaspora in West Africa, Gainesville: University Press of Florida, 1996.

Paul, D. B., 'Eugenics and the Left', Journal of the History of Ideas, 45/4 (1984): 567-90.

Pearce, R. D., The Turning Point in Africa: British Colonial Policy, 1938-1948, London: Frank Cass, 1982.

Pearson, Roger, Eugenics and Race, BCM-Thule, 1966.

Pedersen, S., 'National Bodies, Unspeakable Acts: The Sexual Politics of Colonial Policy-Making', Journal of Modern History, 63/4 (1991): 647-80.

Peel, R. A. (ed.), Marie Stopes, Eugenics and the English Birth Control Movement. Proceedings of a Conference Organised by the Galton Institute, London, 1996, London: The Galton Institute, 1997.

Peel, R. A. (ed.), Essays in the History of Eugenics, London: The Galton Institute, 1998.

Pick, D., Faces of Degeneration: A European Disorder, c.1848-c.1918, Cambridge: Cambridge University Press, 1989.

Ray, L. J., 'Eugenics, Mental Deficiency and Fabian Socialism between the Wars', Oxford Review of Education, 9/3 (1983): 213-22.

Rich, P., 'The Long Victorian Sunset: Anthropology, Eugenics and Race in Britain, c.1900-48', Patterns of Prejudice, 18/3 (1984): 3-17.

Rich, P., Race and Empire in British Politics, Cambridge: Cambridge University Press, 1990.

Roberts, A. D., 'The Gold Boom of the 1930s in Eastern Africa', African Affairs, 85/341 (1986): 545-62.

Rose, S., 'Scientific Racism and Ideology: The IQ Racket from Galton to Jensen' in The Political Economy of Science: Ideology of/in the Natural Sciences, edited by Rose, H. and Rose, S., London: Macmillan, 1976.

Ross, Robert, Status and Respectability in the Cape Colony, 1750-1870: A Tragedy of Manners, Cambridge: Cambridge University Press, 1999.

Schilling, D. G., 'Local Native Councils and the Politics of Education in Kenya, 1925-1939', International Journal of African Historical Studies, 9/2 (1976): 218-47.

Schneider, W. H., Quality and Quantity: The Quest for Biological Regeneration in Twentieth-Century France, Cambridge, Cambridge University Press, 1990.

Searle, G. R., Eugenics and Politics in Britain, 1900-1914, Leyden: Noordhalf International Publishing, 1976.

Searle, G. R., 'Eugenics and Politics in Britain in the 1930s', Annals of Science, 36 (1979): 159-69.

Searle, G. R., 'Eugenics and Class' in Biology, Medicine and Society 1840-1940, edited by Webster, C., pp. 217-42, Cambridge: Cambridge University Press, 1981.

Searle, G. R., The Quest for National Efficiency. A Study in British Politics and Political Thought, 1899-1914, London: The Ashfield Press, 1990.

Searle, G. R., 'Eugenics: The Early Years' in Essays in the History of Eugenics, edited by Peel, R., pp. 20-35, London: The Galton Institute, 1998. 
Semmel, R., Imperialism and Social Reform, English Social-Imperial Thought 1895-1914, London: Allen \& Unwin, 1960.

Shaw, C., 'Eliminating the Yahoos: Eugenics, Social Darwinism and Five Fabians', History of Political Thought, 8/3 (1987): 522-44.

Shaw, C. M., Colonial Inscriptions. Race, Sex, and Class in Kenya, Minneapolis: University of Minnesota., 1995.

Simmons, H. G., 'Explaining Social Policy: The English Mental Deficiency Act of 1913', Journal of Social History, 11/3 (1978): 387-403.

Soloway, R. A., Birth Control and the Population Question in England, Chapel Hill: University of North Carolina Press, 1982.

Soloway, R. A., 'Counting the Degenerates: the Statistics of Race Deterioration in Edwardian England', Journal of Comparative History, 17/1 (1982): 137-64.

Soloway, R. A., Demography and Degeneration: Eugenics and the Declining Birthrate in Twentieth-Century Britain, Chapel Hill: University of North Carolina Press, 1990.

Soloway, R. A., 'From Mainline to Reform Eugenics - Leonard Darwin and C P Blacker' in Essays in the History of Eugenics, edited by Peel, R., pp. 52-80, London: The Galton Institute, 1998.

Sorrenson, M. P. K., Origins of European Settlement in Kenya, Nairobi: Oxford University Press, 1968.

Spencer, John, The Kenya African Union, London: KPI Limited, 1985.

Stepan, N., The Idea of Race in Science: Great Britain, 1800-1960, London: Macmillan Press, 1982.

Stepan, N., 'Eugenics in Brazil' in The Wellborn Science. Eugenics in Germany, France, Brazil, and Russia, edited by Adams, M. B., Oxford: Oxford University Press, 1990.

Stepan, N., 'The Hour of Eugenics'. Race, Gender, and Nation in Latin America, Ithaca: Cornell University Press, 1991.

Strayer, R. W. in conjunction with Jo Murray, 'The CMS and Female Circumcision' in The Making of Mission Communities in East Africa: Anglicans and Africans in Colonial Kenya, 1875-1935, edited by Strayer, R. W., pp. 136-55, London: Heinemann, 1978.

Thomas, L. M., 'Imperial Concerns and "Women's Affairs": State efforts to regulate clitoridectomy and eradicate abortion in Meru, Kenya, c. 1910-1950', Journal of African History, 39/1 (1998): 121-45.

Thomson, M., The Problem of Mental Deficiency. Eugenics, Democracy, and Social Policy in Britain c. 1870-1959, Oxford: Clarendon Press, 1998.

Throup, D., Economic and Social Origins of Mau Mau 1945-1953, London: James Currey, 1987.

Timson, J., 'Human Genetics' in Essays in the History of Eugenics, edited by Peel, R., pp. 112-27, London: The Galton Institute, 1998.

van Zwanenberg, R. M. A., Colonial Capitalism and Labour in Kenya, 1919-1939, Nairobi: East African Literature Bureau, 1975.

Vaughan, M., 'Idioms of Madness: Zomba Lunatic Asylum, Nyasaland, in the Colonial Period', Journal of Southern African Studies, 9/2 (1983): 218-38. 
Vaughan, M., Curing Their Ills - Colonial Power and African Illness, Stanford: Stanford University Press, 1991.

Webster, C., 'Introduction' in Biology, Medicine and Society 1840-1940, edited by Webster, C., pp. 1-13, Cambridge: Cambridge University Press, 1981.

Willis, J., 'Thieves, Drunkards and Vagrants: Defining Crime in Colonial Mombasa, 1902-32' in Policing the Empire: Government, Authority and Control, 1830-1940, edited by Anderson, D. M. and Killingray, D., pp. 219-35, Manchester: Manchester University Press, 1991.

Wintle, M. (ed.), Culture and Identity in Europe, Aldershot: Avebury, 1996.

Wrigley, C. C., 'Kenya: the Patterns of Economic Life, 1902-1945' in Oxford History of East Africa, edited by Harlow, V. and Chilver, E. M., pp. 209-64, Oxford: Oxford University Press, 1965.

Wylie, D., 'Confrontation Over Kenya: The Colonial Office and Its Critics, 1918-1940', Journal of African History, 18/3 (1977): 427-47.

\section{Unpublished theses}

Beuschel, Gail E., 'Shutting Africans Away: Lunacy, Race and Social Order in Colonial Kenya, 1910-1963', PhD thesis, University of London, 2001.

Bin Harun, H., 'Medicine and Imperialism: a Study of the British Colonial Medical Establishment, Health Policy and Medical Research in the Malay Peninsula, 1786-1918', PhD thesis, University of London, 1988.

Burton, A., 'Wahuni (The Undesirables): African Urbanisation, Crime and Colonial Disorder in Dar es Salaam, 1919-1961', PhD thesis, University of London, 2000.

Lyons, A. P., 'The Question of Race in Anthropology from the Time of Johann Friedrich Blumenbach to that of Franz Boas', PhD thesis, Oxford University, 1974.

Mungai, J. M., 'Dendritic Patterns in the Somatic Sensory Cortex', PhD thesis, University of London, 1966.

Redley, M. G., 'The Politics of a Predicament: The White Community in Kenya 1918-1932', PhD thesis, Cambridge University, 1976.

Tilley, H., 'Africa as a Living Laboratory: The Colonial Research Survey and the British Colonial Empire', PhD thesis, University of Oxford, 2001.

Worboys, M., 'Science and British Colonial Imperialism, 1895-1940', PhD thesis, University of Sussex, 1980.

Young, T., 'The Eugenics Movement and the Eugenic Idea in Britain, 1900-1914', $\mathrm{PhD}$ thesis, University of London, 1980. 